\title{
Central venous catheter-related nosocomial bloodstream infections in children on long-term parenteral nutrition: the impact of the move to a new university hospital
}

\author{
M-L Valdeyron ${ }^{1 *}$, N Peretti $^{2}$, J Grando ${ }^{1}$, P Vanhems $^{3}$ \\ From 3rd International Conference on Prevention and Infection Control (ICPIC 2015) \\ Geneva, Switzerland. 16-19 June 2015
}

\section{Introduction}

Insufficient training in CVC management contributes in the development of CRBSIs

\section{Objectives}

This study evaluated the impact of moving to a new university paediatric hospital on the incidence of central catheter-related blood stream infections (CRBSIs) among children on long-term parenteral nutrition.

\section{Methods}

This retrospective study covered from April 2007 to March 2014, starting a year prior to move the children to a new hospital in April 2008, and continuing for 6 years following the move. During this observational period, data from all children hospitalized in a hepato-gastroenterology and nutrition unit of a paediatric tertiary hospital who received parenteral nutrition (PN) for more than 15 days were analysed.

\section{Results}

During this 7-year study, 183 children aged $4.6 \pm$ 0.5 years received prolonged PN. Intestinal diseases were the main aetiologies $(89 \%)$, primarily short bowel syndrome (18.4\%), Hirschsprung disease and Chronic Intestinal Pseudo-Obstruction syndrome (CIPO) (13.5\%) and inflammatory bowel disease (13.8\%). The mean durations of hospitalization and of PN during hospital stay were, respectively, $70 \pm 2.1$ and $55.7 \pm 3.6$ days. During the study period, 151 CRBSIs occurred in 77 children

${ }^{1}$ Infection Control and Prevention, Hospices Civils de Lyon - Groupement Hospitalier Est, Bron, France

Full list of author information is available at the end of the article (the attack rate was $42 \%$ of all patients), i.e. 14.8 septic episodes per1000 PN-days and 12.0 septic episodes per1000 CVC-days. No patient died of a central venous catheter-related infection.

However, following the move from the older hospital to the newer one, the rate of CRBSIs significantly doubled, from 3.9 to 8.8 per $1000 \mathrm{CVC}$-days $(\mathrm{p}=0.02)$. During the following 4 years, the incidence of CRBSIs tended to increase between the $2^{\text {nd }}$ and the $5^{\text {th }}$ year after the move: $11.3(\mathrm{p}=0.5) ; 21.4(\mathrm{p}=0.01) ; 17.3(\mathrm{p}=0.4), 20.3$ per 1000 $(\mathrm{p}=0.6) \mathrm{CVC}$-days. After evaluations by the Department of Infection Control, nurse training and stabilization of the nursing team, the incidence decreased significantly from 20.3 to $11.1 / 1000 \mathrm{CVC}$-days during the $6^{\text {th }}$ year after the move $(\mathrm{p}=0.01)$.

\section{Conclusion}

Our results revealed the deleterious impact of the hospital move on the CRBSI incidence rate in hospitalized children on PN, and the necessity in having a trained, experienced and stable team of nurses to prevent nosocomial infections.

\section{Disclosure of interest}

None declared.

\section{Authors' details}

${ }^{1}$ Infection Control and Prevention, Hospices Civils de Lyon - Groupement Hospitalier Est, Bron, France. ${ }^{2}$ Pediatric Hepato-gastroenterology and Nutrition Department, Hospices Civils de Lyon - Groupement Hospitalier Est, Bron, France. ${ }^{3}$ Infection Control and Prevention, Hospices Civils de Lyon, Lyon, France. 
doi:10.1186/2047-2994-4-S1-P206

Cite this article as: Valdeyron et al: Central venous catheter-related

nosocomial bloodstream infections in children on long-term parenteral

nutrition: the impact of the move to a new university hospital

Antimicrobial Resistance and Infection Control 2015 4(Suppl 1).P206.

Submit your next manuscript to BioMed Central and take full advantage of:

- Convenient online submission

- Thorough peer review

- No space constraints or color figure charges

- Immediate publication on acceptance

- Inclusion in PubMed, CAS, Scopus and Google Scholar

- Research which is freely available for redistribution

Submit your manuscript at www.biomedcentral.com/submit
C Biomed Central 